\title{
SOBRE UNA "POESÍA QUE SE PIENSA EN EL LENGUAJE" • ¿HACIA UNA NUEVA VANGUARDIA EN LA POESÍA ESPAÑOLA?
}

On "a poetry thought in language". Towards a New Avantgard in the Spanish poetry?

\author{
MARIO MARTín GIJÓN \\ UNIVERSIDAD DE EXTREMADURA (ESPAÑA) marting@unex.es
}

RECIBIDO: 12 DE FEBRERO DE 2018

ACEPTADO: 12 DE MARZO DE 2018

RESUMEN: En la última década puede observarse una renovación de las poéticas en España, tras un largo periodo de hegemonía de la lírica realista o figurativa. Aunque aún lejos de cuestionar el predominio a nivel editorial de la conocida como "poesía de la experiencia", sí es evidente que el descrédito de la vanguardia va siendo superado y que, en formas múltiples y personales, alejadas de ningún movimiento grupal, muchos de los poetas jóvenes vuelven a poner en cuestión el lenguaje, cuestionamiento que suele relacionarse con un intenso tratamiento de lo corporal. Todo ello relacionado con una mayor lectura de la poesía latinoamericana y de otras tradiciones. En este artículo se pretende acercar al lector a la obra de una serie de poetas, jóvenes en su mayoría, esbozando sus rasgos más diferenciales, que pueden resumirse en esa creencia en una vOz oracular del cuerpo, la disolución en una polifonía de voces, y una presencia cada vez mayor de lo político.

PALABRAS CLAVE: Poesía española, vanguardia, lenguaje, artes, cuerpo.

ABSTRACT: In the last decade, a change can be perceived in Spanish poetics, after the long hegemony of realistic or figurative poetry. Even if we are still long from seeing "the poetry of experience" being challenged, there are some signs that the disrepute of the Avantgarde will be soon a thing of the past. There is a more solid reading of Latin-American poets and other national traditions. Many young poets, without forming a group, are questioning the language, a move which comes along with a centrality of body in their works. In this paper we try to describe the main characteristics of some of the most valuable young Spanish poets, isolating some of their important traits, such as the belief in an oracular voice of body, the dissolution in polyphony and an increasing presence of the political.

KEYWORDS: Spanish poetry, Avantgarde, language, arts, body.

Martín Gijón, Mario.

"Sobre una "poesía que se piensa en el lenguaje”. ¿Hacia una nueva vanguardia en la poesía española?".

Kamchatka. Revista de análisis cultural 11 (Julio 2018): 145-162

DOI: 10.7203/KAM.11.11497 ISSN: 2340-1869

Monográfico LECTURAS DEL DESIERTO: NUEVAS PROPUESTAS POÉTICAS EN ESPAÑA 


\section{NUEVAS EMERGENCIAS}

En los últimos años puede constatarse la emergencia de poéticas que, desde ángulos muy diversos, apuestan por una concepción indagatoria del lenguaje como vehículo para apresar el flujo inaprehensible de la conciencia. Ciertos autores, como el poeta y crítico Eduardo Moga perciben un agotamiento de la corriente figurativa y neorrealista hegemónica durante casi tres décadas y el auge de una "tendencia neovanguardista, una nueva corriente experimental, que persigue la subversión léxica y sintáctica" (2015a) o, en palabras de Óscar de la Torre, una visión del texto poético como "espacio múltiple e interactivo, heterogéneo y proteico" (2016, 17). Cabe destacar que, frente a una cierta autarquía lírica en promociones anteriores, poetas como el uruguayo Eduardo Milán, el chileno Raúl Zurita o el cubano José Kozer son referentes ineludibles para la mayoría de los autores que podrían sentirse identificados con estos planteamientos. Otro dato a tener en cuenta es la extrema atención que a otras artes y formas de expresión extratextuales muestran no pocos de ellos, y que se plasma en proyectos comunes con artistas de vanguardia, cuando no en la propia vocación poliartística. Por citar algunos ejemplos, Ángel Cerviño es un reconocido artista plástico, con una trayectoria de casi tres décadas y numerosas exposiciones individuales. Enrique Cabezón es artista gráfico y vocalista de la banda de rock EnBlanco, donde ha versionado algunos de sus poemas. Óscar Curieses, doctor en literatura comparada con una tesis sobre el cine de Paul Auster, trabaja como pinchadiscos en un conocido local de Lavapiés y su último libro incluye un $\mathrm{CD}$ con improvisaciones sobre sus poemas por un grupo de audioperformances. Julio César Galán dirigió durante años un "centro de investigación y desarrollo de actividades teatrales" y es autor de varias obras dramáticas. Alejandro Céspedes "reescribió en imágenes" su último poemario, en una serie de videopoemas titulados La libertad del títere. El libro Vitral de voz, de Carlos Fernández López, se transformó en la performance Disolución, y una sección de dicho poemario se basa en la instalación Materiales para el desastre, del artista uruguayo Héctor Solari, acompañando su exposición en distintas galerías europeas. Esther Ramón coordina el taller La flecha en el blanco, que potencia el diálogo de la poesía con la pintura, fotografía o escultura y, recientemente, coordinó el proyecto Digging, que unía poemas de autores españoles con obras artísticas expuestas en el Lofoten International Art Festival (Noruega).

En esta colaboración con artistas innovadores se reproduce aquella dialéctica de confluencias y alianzas que, como expusiera Pierre Bourdieu, se desarrolló en muchos movimientos de vanguardia que, desde discursos tan distintos como la pintura y la poesía, coincidían en su rechazo de las estéticas dominantes (1992, 389). Como analizara el sociólogo francés, la lucha por la autonomía del arte unió en su momento a literatos y artistas plásticos, que debían crear un espacio que se rigiera solo por el reconocimiento entre los pares. Salvando las distancias, todo parece indicar que, en un panorama poético como el español, extremadamente institucionalizado por una red ya antigua de acuerdos entre editores, críticos y poetas consagrados, que con la complicidad de las administraciones públicas y la concesión de premios otorgados de antemano perpetúa los mismos nombres y las mismas estéticas, esas colaboraciones con artistas aportan una producción de valor añadida que llama la atención sobre poéticas diferenciadas. Ello tiene igualmente razones de necesidad interna pues, como describiera la 
profesora Évelyne Lloze en su sugestiva teoría del hecho poético, donde sostiene que existe "un lien immérmorial, d'un côté avec la peinture, l'image et de l'autre avec la musique, le son, et à chaque fois une illimitation, un déportement vers d'autres langages esthétiques [...] qui témoignent à l'envi du caractère rebelle du texte poétique enclin à exacerber ses "pouvoirs" dans des jeux de détours et de rencontres libérateurs" (2013: 72).

Con todo, no estamos ante ningún movimiento colectivo: no existe ningún acuerdo programático, y los poetas de los que hablaremos llevan a cabo, más allá de afinidades puntuales que serán señaladas, obras muy heterogéneas. Mejor así, pues, como dijera Philippe LacoueLabarthe, "un poème n'est effectivement poème que pour autant qu'il est absolument singulier. C'est là, on ne peut en douter, une définition de l'essence de la poésie (c'est-à-dire de ce qui, par soi, n'est décidément rien de "poétique"): il n'y a la poésie, la poésie n'advient ou n'a lieu, chaque fois par conséquent remise en cause, que comme l'événement de la singularité" (2015: 63). El teórico francés precisaba más adelante los modos en que una voz singular surge en poesía mediante el cuestionamiento del lenguaje, hablando de "la "solitude" du poème, et ce qui l'oblige, d'une obligation aussi rigoureuse que l'obligation de parler, non pas à "inventer" un langage singulier ou à constituir de toutes pièces un idiolecte, mais a défaire le langage (sémantiquement et syntaxiquement), à le désarticuler et à le raréfier, à le couper selon une prosodie qui n'est ni celle de la langue ni celle de la poésie antérieure, à le condenser, jusqu’à atteindre ce noyau dur, cette sourde résistance à quoi l'on reconnaît une voix singulière, c'est à dire départagée de la langue et du langage" (85). Cada poética de las que veremos, no puede dudarse de ello, muestran una marcada singularidad (Mora 2006), hecha de un difícil camino personal al encuentro de la propia vOZ.

\section{LA VOZ ORACULAR DEL CUERPO}

Aunque no encuadrables en los terrenos más rupturistas, cabe mencionar la evolución y emancipación en cierto sentido de la obra de poetas que empezaron en la estela de José Ángel Valente y Antonio Gamoneda, quizás los maestros más indiscutibles entre los poetas españoles, y bajo el magisterio cercano del neosurrealismo oracular de Juan Carlos Mestre.

Esther Ramón (Madrid, 1970) es autora de ocho poemarios en los que muestra un reconocible imaginario propio, hecho de imágenes inquietantes, abiertas a la interpretación que, en Tundra (2002), Reses (2008) y Caza con hurones (2013) busca apresar por un momento la realidad fluyente y la violencia perceptible en la naturaleza, buscando "leer las palabras que escribe la corriente" $(2002,30)$ y "tensar el ojo indirecto" (33) para captar las verdades que sobre nosotros puedan transmitirnos los animales, la primera de las cuales es la inestabilidad permanente del ser. En su obra, la naturaleza, la fauna y la flora, pero también los seres engañosamente llamados inertes, son la red simbólica que abarca todos los propósitos de su decir.

Animales emblemáticos, como el hurón (cazador subterráneo, que evoca la búsqueda de un lenguaje oculto por debajo de los tópicos) hacen su aparición, como lo hacen, desde el primer poema, las aves que adquieren múltiples significados relacionados con la vocación poética.

Nada más lejos, por supuesto, que una visión armónica e idealizada de la naturaleza en Esther Ramón. Por el contrario, el mundo poético de Esther Ramón está regido por una continua 
violencia, como se hará más palpable en su poemario Reses (2008). Aquí, las cabezas de ganado, anagrama de todos los seres, son conducidas al sacrificio, tras ser sometidas a complejos rituales de violencia. Con una sensibilidad que parte del precursor tratamiento del tema en el lorquiano "New York (Oficina y denuncia)" y del poema "Ternera acosada por tábanos" de Blanca Varela, entre otros, el repetido tema del sacrificio de los animales (vacas destazadas, ovejas en un incendio), descrito con descarnadas imágenes ("las desmiembran y quedan sin forma, reducidas, con los músculos aún latiendo. Grandes arcones frigoríficos. Pájaros cayendo” (2008, 64)) refleja la dinámica despiadada de un mundo que no es sino un "tablón / donde amigos / y enemigos / crujen al unísono" (31). Con todo, el poemario deja líneas de fuga para la esperanza, en las imágenes de las aves o de los caballos blancos en libertad: "Primero fue una ligera brisa. Luego el viento, el sonido de los cascos. Relinchos. Y al fin la blancura que no se puede mirar. / Encima de ellos. La velocidad" (91).

Poeta heracliteana, tan lejos del idealismo platónico como del cinismo de Diógenes, Esther Ramón se propone "vivir sin casa, / sin toneles. / Vivir en la cascada" (2013, 22). En sus libros Grisú (2009) y Sales (2011), el trabajo de los mineros evoca el de la poeta, ahondando en la gravedad de lo aparentemente inamovible, intentando asumir "la forma en su peso / de aves muertas" (2011: 17). Frente a aquel bellísimo Piedras, de Roger Caillois (2011), la inmovilidad no puede ser portadora de belleza para Esther Ramón, quien en su libro, Desfrío (2015a), con poemas de violencia soterrada que esbozan catástrofes aéreas y conflictos sociales, conjuga las dos isotopías, mineral y animal, en su búsqueda de sentido concebida como una extracción dolorosa y a la vez amante de la perecedera materia, en lo que Antonio Méndez Rubio definiera como "una mística pobre, una mística desprovista de mística, materia de resistencia en la confianza, inversa a la idea de elevación" (2015a: 83-84). En sus dos últimos libros, ya sea mediante el poema extenso en Moradas (2015b), donde prosigue el imaginario animal de Reses, ahora desde la fauna salvaje, o en la brevedad de en flecha (2017), Esther Ramón mantiene una coherente idea de la poesía como esfuerzo que sirve para "sostener el alfabeto de lo vivo" (2017: 69).

Me gustaría ahora hablar de una tríada de poetas que, aunque cada un posea un estilo propio, tienen algunas afinidades. Me refiero a Marcos Canteli, Benito del Pliego y Pablo López Carballo. En rigor, me parece que el calificativo de "poeta de la mirada" que Eduardo Moga aplicara a Canteli, sería válido para todos ellos, aunque con distintas modulaciones. En el asturiano, es una mirada consciente, desentumecida, que trata de ir "cada día forzando la visión. Para que el mundo aparezca" (2003: 33) como se dice en enjambre; el ojo es el pulmón que suministra aire, aunque sea velado, a la escritura en su sombrío (2005), sin que por ello la mirada "fabrique" ninguna realidad que no estuviera ahí, esperando el ángulo para ser vista.

En la mirada de Canteli se refleja la evolución de su poesía antes señalada. Si en sus primeros libros se trataba de "despertar, desentumecer / la mirada" e ir "forzando la visión. Para que el mundo aparezca", aplicando el ojo como "un nervio tenso y descarnado" que captara las relaciones desapercibidas por la mirada pasiva, a partir de Catálogo de incesantes (2008) esta mirada se ha vuelto menos tensa y más abierta, pues aunque todo sigue "ocurriendo por lo visible", Canteli se entrega al volátil azar del paseante, y prefiere "darse a córnea libre para rebosar más tarde" sobre la página en blanco en un trabajo de ardua composición. 
Por su parte, Benito del Pliego llama la atención sobre la ineludible reflexividad de esta mirada y su calidad metapoética y se pregunta en Merma "qué nos mira" a través de nuestra vista cuando la forzamos, este "mirar que su visión avista" (2009: 17). A veces, la mirada paradójicamente se vuelve hacia dentro. Benito del Pliego, aunque se entregue a una mirada indagatoria para que "un sesgo deseante mire hasta leer" los signos inscritos en el mundo, a veces, ante la constatación de que "se mira en el mundo y nada responde", prefiere, centrándose sobre la ineludible reflexividad de esta mirada "verse con los párpados cerrados, contemplar aquello que los atraviesa". Precisamente los párpados, frontera entre la luz y la oscuridad, entre el mundo externo y el sueño, adquieren una especial importancia en la obra de Rafael-José Díaz, consecuente con su poética de la liminalidad, que en Los párpados cantivos (2003) evoca unos "ojos que miran adentro de sí mismos", adentrándose en un sueño que impugne el tiempo y traiga el añorado cuerpo amado. Díaz es también autor de una novela llamada, sintomáticamente, El interior del párpado (2014). La imagen del "párpado" y del "parpadeo", de lo alterable y liminal de la visión, ha sido expuesta por el propio Marcos Canteli en su tesis doctoral, luego publicada en forma de libro, Del parpadeo. 7 poéticas (2014), donde reivindica el legado de poéticas coetáneas a la hegemonía de la poesía realista y oscurecidas por ésta, como la de Olvido García Valdés, Ildefonso Rodríguez, Miguel Suárez o, por supuesto, José-Miguel Ullán.

La idea de que la mirada nunca es inocente, de que en ella hay siempre una deformación, ha sido quizás tratada de la manera más consecuente por Pablo López Carballo, ya desde su primer libro, Sobre unas ruinas encontradas (2010) cuya primera parte, "Pretexto del ojo", muestra una tematización muy amplia de una mirada "artífice", inquisitiva, deformada, sabedora de que en los resquicios se ocultan a veces las mejores gemas. El leonés considera que "escribir poesía es mirar y pensar. Entiendo el "ojo" como concepto general, en el que se incluiría al resto de sentidos" (2011).

En su siguiente poemario, Quien manda uno (2012) se postulaba una socavación radical del lenguaje a través de la resemantización de lo azaroso, en La dictadura de la perspectiva, el cuestionamiento de lo visible y lo decible parte del sueño de armonía que identificamos con el Renacimiento, y por ello Paolo Uccello, creador de la perspectiva, y Piero della Francesca, con su lienzo La ciudad ideal, se convierten en referentes interpelados, pues en sus cabezas "se dibuja un mundo, el único habitable" de líneas imperecederas. La realidad que nos tocó vivir, sin embargo, es mucho más borrosa. "Todo se ensombrece cuando lo miro. Definir / como reptar en semejanzas. En la carencia", comienza el poema "Alucinación de las parcelas", que escenifica de modo magistral la arbitrariedad que subyace a nuestros puntos de referencia: "Coloco estacas / y aparece el paisaje” (2017: 24). Y es que la poesía de López Carballo, reacia a la identificación fácil con el lector, se sustenta sobre una honda preocupación fenomenológica compatible con la rara belleza de ciertas imágenes: "Los límites toman forma, como la precisión / de tu indiferencia” (bajo el título La precisione dell'indifferenæa se publicó recientemente una antología de este autor traducida al italiano). Por eso, la poesía nos sirve como advertencia de que "las leyes no funcionan" y de que a lo que nos limitamos habitualmente es a "dividir lo homogéneo / en lugar de entenderlo".

Eso sí, como se desarrolla en poemas como "Trabajo perpetuo" (43), esta indagación fenomenológica se lleva a cabo con la lúcida ironía de un Sísifo resignado ("He movido, a diario / 
el proyecto que a nadie interesa") que vuelve sobre sí su escepticismo con fórmulas sorprendentes ("No sé si el escroto aguantará el peso / del párpado en la llanura") y persiste en la confianza, pese a su precariedad, en la textualidad del mundo, en que "tender hilos / llenarlo todo de hilos" es la única manera de descubrir las relaciones que lo hagan comprensible. La imagen de la araña, en ese mismo poema "Casa en el río o alucinación de la presencia", en un verso memorablemente ambivalente (36) (“Arañas en las raíces") recuerda la metáfora de la escritura empleada por Lezama Lima, que se asocia con un animal que a partir de sí mismo crea un mundo propio, con la frágil red de las palabras y que estructurase el poemario Araña (2005), de Ana Gorría, una poeta cercana generacionalmente y en parte también estéticamente a la poética de Pablo López Carballo. Por ello también la metáfora del hilo es recurrente en todo el libro, desde el poema "Hilar" al final "Tirar del hilo" (73-78). Todo ello a sabiendas de la precariedad de nuestra existencia y la voluntad consiguiente de "no dejar de ser huésped", al margen de los simulacros de posesión y espectáculo del capitalismo, la obsolescencia programada por la productividad y el declive de la atención, tendencias claras de nuestros días ante los que el poeta se muestra crítico: "Ya solo se hacen cosas / no se describen / [...] surgió un mundo y nos quedamos sin dedos para señalarlo [...] ¿mirar es proyectarse?” (42). Una reflexión, sobre ese "afuera que no nos pertenece" en el que resuenan los análisis de Antonio Méndez Rubio sobre "la desaparición del exterior" (2012).

Joan de la Vega (Santa Coloma de Gramanet, 1975) se ha caracterizado desde su inicial Ladino (2006) por una tensión existencialista, angustiado por la "interrogación absoluta y constante del existir" (15) a la que enfrenta el "ser ardiente convocado para morir" (13) en fórmula netamente heideggeriana y que poéticamente bebía del esencialismo último de José Ángel Valente, pero también de poetas en catalán como Màrius Sempere, pues hablamos de un autor escindido entre dos lenguas, el catalán y el castellano, dualidad que ve simbolizada en su nombre y apellidos: "Las extremidades de mi nombre moldean dos rostros opuestos, dos lenguas enfrentadas y dos hombres extremos. Si pudiera abrir las venas, colmaría al ser que se encierra" (69). En Ladino, el sujeto poético braceaba en la soledad de la urbe, reacio al "libro de la comunidad" y que sólo confiaba en el "sueño verbal" para reunir un precario sentido a la existencia. En Joan de la Vega se percibía un ansia de utilizar el lenguaje como el umbral que nos traspone a otro estado más alto de la vida, por encima de la superficie de los días iguales. La palabra poética es por ello "subversión o revelación", desmontaje de un orden rechazado desde una perspectiva revolucionaria, y revelación de esa realidad sólo avistada en vivencias efímeras que suelen acaecer en el amor, la amistad, o en la contemplación de la naturaleza.

En efecto, a partir de La montaña efímera (2011), De la Vega ha encontrado en integración con los parajes naturales, especialmente en sus cercanos Pirineos, una vigorizante vuelta a lo elemental y un paso adelante del flâneur citadino hacia la libertad de las montañas, que, a pesar de la diferencia de estilos, y de que los referentes de Joan de la Vega, aparte de su propia vivencia biográfica, sean otros poetas más bien ocultos como el Sergio Gaspar de Aben Raz̨in, o José Corredor-Matheos, sobre todo en El jardín de arena, hace vislumbrar un asomo de lo que significa, por ejemplo, la poesía de Philippe Jaccottet para la literatura francesa.

La montaña efímera se divide en dos partes claramente diferenciadas pero complementarias. En la primera, "La última cima", se manifiesta esta creencia en la naturaleza como último refugio 
y una integración en el paisaje poco común en nuestras letras. Los textos, compuestos por breves párrafos en los que una impresión sensorial de la montaña expresada en forma de metáfora lleva a un desarrollo que desemboca en una expresión de fe impulsada hacia delante, van configurando una exaltante letanía de admiración e integración en la montaña, transmitida al lector gracias a un léxico preciso y a la vez eufónico, que nos sitúa entre valles y arroyos de montaña, entre las ramas de abetos y el aletazo lejano de las aves, en el frío de los lagos glaciales y la aspereza de los roquedos, en el vértigo del abismo y el desafío de la altura.

Pero se trata de un difícil diálogo con un entorno que nos habla en un lenguaje que apenas logramos aprehender. Por ello, más que de personificación, conviene hablar de la inteligencia del paisaje. Así, el arroyo de montaña parece hablar con "palabras dictadas por una lengua extinguida" (2011, 29) y un cielo nublado "medita aguaceros" (32). En una de las imágenes más barrocas se habla de la tormenta "que agita su teorema de muerte parpadeando ningún nombre" (32). Se combinan la naturaleza y la abstracción, en una extraña inteligencia superior a la que pueda alcanzar la mente humana. Permanentemente este lenguaje mudo, el del "valle sin nombres" que, sin embargo, dice tanto. El viajero ha llegado a "arboledas perdidas, donde hallar ningún nombre" (34), y ha llevado consigo "los nombres al lugar sin nombre" (34) con una percepción adánica de una naturaleza virgen de glosas y discursos.

Se trata, en definitiva, de la sabiduría de los seres inertes, que han existido antes de que el primer hombre articulase su pensamiento, y cuya máxima expresión es la noche estrellada, la noche solemne frente a la que los alpinistas refugiados en sus tiendas son "hombres retorcidos como gusanos" (39); la inmensidad de los espacios siderales que asustara a Pascal, la "opacidad sin nombre" que se convierte en el "último amor, último asilo" (35). Así, las piedras erosionadas han enmudecido, se han desprovisto de sus nombres, son "cantos rodados", que si incitan a un canto imposible, "encienden un lenguaje inasible, a golpes" (30). Y es una sabiduría que, al tiempo que eterna se renueva y como tal, engendra la "simiente de la plenitud, solaz y desmemoriada" (36).

Atraído por el budismo y el hinduismo por su aceptación de nuestra pertenencia a los ciclos naturales, Joan de la Vega se atreve con una poesía de cierto carácter sapiencial en Una luz. que viene de fuera (2012), dividido en dos partes, "Samsara" y Las flores del Dharma", que intenta recoger las enseñanzas del taoísmo o el ejemplo vital del japonés Matsuo Bashō, maestro del haiku, que sin duda influyó su libro 365 baikus y un jisey (2012), donde reafirma la más alta existencia que encuentra entre cumbres ("Entre montañas / pierdo mi soledad. / Vida a raudales" (23)) y su rechazo a lo urbano ("Miro hacia el bosque. / Infierno de ocio y odio / vuestra ciudad" (31)), en una forma que llega a dominar aunque sin llegar a la ataraxia ideal asiática, pues una y otra vez repunta el deseo de permanencia del individuo: "Valle dormido. / Quisiera dejar rastro / sin despertarme" (23). Su penúltimo libro, Y tú, Pirene (2013) evoca esa figura mitológica amada por Hércules, que al enterrarla formó la cadena montañosa. Libro dedicado "a todos los amores caídos. En especial, los muertos", se concibe como un punto final, donde alternan poemas en verso y en prosa, y en el que una voz sepultada ("Bajo tierra" se titula la sección central del libro) espera en su soledad el difícil encuentro con el lector que actualizará y diversificará significados pues, se nos dice, "decir yo / es esperar / inmerso / la llegada de otros nombres" (13). 
José Antonio Llera (Badajoz, 1971), cuyos dos primeros libros, Preludio a la inmersión (1999) y El monólogo de Homero (2007) poco común muestra de dos largos poemas-libros en metros clásicos de endecasílabos y heptasílabos, de neta impronta culturalista, no ocultaban su deuda hacia T.S. Eliot, el Juan Ramón Jiménez de Espacio o incluso algunos libros de Antonio Colinas, emprendió en El sindrome de Diógenes (2009) un camino de mayor originalidad, donde la tradición clásica sigue presente pero gana fuerza la presencia de una dicción surrealista cercana al Lorca de Poeta en Nueva York o a Miguel Labordeta (a ambos ha dedicado el autor sendos libros de ensayo) y sus poemas se abren a una temática de las sensaciones en el mundo contemporáneo, de escenarios urbanos donde la velocidad y el deseo suministran la materia prima para la voz poética de un sujeto enunciador en los márgenes de la sociedad, un lugar donde el hombre aislado se encuentra con el misterio y donde amenaza el espectro de la locura, a cuya representación artística Llera dedicara un atípico e iluminador ensayo: Rostros de la locura. Goya. Cervantes. Wiseman (2013a). En una conjunción afortunada entre la razón cínica sloterdijkiana y el hedonismo encontramos versos de un humor negro como el del conductor que mientras acelera parodia el célebre axioma de Wittgenstein sobre el lenguaje: "Los límites del salpicadero son también los de mi cuerpo". Y es que en el basamento de la construcción lírica de Llera está el aserto de que "sólo nos conmueve lo que no aspira a la permanencia" y de ahí la celebración del collage, de la basura acumulada como un paciente del síndrome que da nombre al poemario. Su último libro, Transporte de animales vivos (2013) amplía y enriquece esa meditación sobre los espacios silenciados de la urbe (quirófanos, túneles, autopistas) y sus desubicados habitantes, en un diálogo subyacente con el Lorca de Poeta en Nueva York (al que Llera ha dedicado un completo estudio): la liebre atropellada es yuxtapuesta a los suicidas del viaducto en el poema "C-3 (Aranjuez-Atocha)" : "Y sin embargo, recuerdo ahora que en mi casa siempre se celebraba la ocasión en que mi padre, al volante, atropellaba una liebre. Mi madre limpiaba la sangre del animal con papel de periódico" (2013b: 16). Por su parte, los terneros que recorren Europa hacinados en camiones son enfrentados a sus consumidores (17-18), no menos enclaustrados en sus vidas compartimentadas, en una visión sin paliativos sobre los ritmos contemporáneos, donde "los ciclos del capital" son igualados con "los ciclos de la quimioterapia" y al fin y al cabo "vivir es un placebo" (25). Para Rafael Morales Barba, se trata de una "poesía bronca y reflexiva, sarcástica, comprometida, atormentada, sin pacto trae el versículo de Llera en definitiva, sin maniera, donde la memoria percute y expone heridas que se quieren conjurar. El flâneur atormentado ante el mapa de la carencia de ser o la pesadilla" (2017: 339).

Yaiza Martínez (Las Palmas de Gran Canaria, 1973), en libros como Rumia Lilith (2002), o Siete. Los perros del cielo (2010), compartía con poéticas anteriores el uso del versículo y la imagen visionaria, o la sensibilidad animal en El hogar de los animales Ada (2007) cercana a la desarrollada por Esther Ramón. La poeta canaria había destacado por su manera de introducir la extrañeza dentro de lo cotidiano, en especial de las relaciones familiares, sobre todo en Agua (2007), libro concebido como "trama de recuerdos que escapa al psicologismo" en palabras de la crítica Rosa Benéitez (2009), gracias a una palabra vista como fluido que, en Caoscopia (2012) es sometida a un proceso de análisis simultáneo a la vivencia. En este libro el desdoble se produce entre el texto y las notas a pie de página, que a su vez dan lugar a otras notas, y donde la poeta se propusiera "plasmar el goteo de la conciencia" (79), reproduciendo, con pathos científico, el caos mientras "tejo la penumbra / y albergo fe al final de un túnel” (27). La experiencia amorosa se confunde 
con su plasmación en la palabra ("ensayo tu cuerpo lo amaso lo siento papel" (69)) y el texto es sometido a un análisis de la misma secuencia repetida tres veces: "el ser", "el no ser", "la voz del amor", "en el lenguaje", con la confianza de que así se obtendrá una fotografía de la conciencia: "escucha / patrón sutil y recrea".

Óscar Curieses (Madrid, 1972) incide en la descomposición de la forma y de las fórmulas para, a través de una obsesiva y escabrosa indagación personal, llegar a los fondos de la conciencia. En Sonetos del útero (2007), Curieses somete al soneto a un continuo proteísmo que va de la ausencia de rima al poema en prosa bajo el cual, sin embargo, sigue latiendo su forma inconfundible, de manera paralela a cómo en este poemario las emociones filiales o amorosas son descompuestas y despojadas de todo ropaje sin por ello perder su veracidad. Su escritura se completa con una ortografía heterodoxa, que carga de connotaciones inéditas las palabras, con neologismos tan afortunados como "biolencias", para denotar la agresividad lenta y continuada ejercida sobre los asuntos vitales. Y es que tanto en sus sonetos como en su siguiente poemario Dentro (2010), el imaginario intrauterino de Curieses se explica por una honda conciencia de la homología entre el crear poético y el deseo de renacer continuamente. Su último libro, hay una jaula en cada pájaro (2013a) reelabora textos de sus poemarios anteriores, entremezclándolos con nuevas secciones, entre las que destaca la sección "Bichos de tinta o un falso bestiario", donde los poemas surgen partiendo de los trazos pictóricos de Luis Martínez de Merlo, aunque como apunta Pablo López Carballo, no existe una intención ekfrástica en el poeta, sino una voluntad de "relacionar dos artes, sin recurrir por ello a la imitación, respetando sus lógicas internas" (2014, 186), común a la mayoría de estos poetas, pero que en el caso de Curieses, autor de Hombre en azul (2013b), una biografía ficticia sobre el pintor Francis Bacon, se relaciona con una búsqueda panartística del yo.

\section{DESDECIR LA DESDICHA, O LA DISOLUCIÓN EN UNA POLIFONÍA DE VOCES}

Ángel Cerviño (Lugo, 1956) tenía ya una consolidada trayectoria como artista visual cuando en 2009 publicó en la prestigiosa editorial DVD su primer poemario, El ave fénix solo caga canela. El "ejercicio de autonomía" que, según postulara Cerviño en uno de los aforismos de su Kamasutra para Hansel y Gretel $(2007,17)$, constituye el arte frente a los simulacros en serie y el discurso uniformador de los medios de comunicación de masas se traspasa a la escritura en un libro que dialoga lúdicamente con el psicoanálisis desde el título, referencia a una frase de Lacan, cuya convicción de que el inconsciente está estructurado como un lenguaje sirve de punto de partida a un lúdico "complot antirretórico" tramado en "conjeturas que parecen versos" y "palabras que parecen contraseñas" $(2009,25)$ con el fin de acceder a un yo inevitablemente fragmentado y atiborrado de datos contradictorios, pero que como el ave fénix renace continuamente de las cenizas de su banalidad nutrida por la lógica capitalista, hecha a base de "arte gratis" y el "remix" de innumerables monstruos de Frankenstein. Como analizara José Luis Gómez Toré (2010), en lugar de una previsible protesta contra el caos, el poeta, haciendo de la necesidad virtud, se sumerge en ese magma de voces para romper con los significados heredados, y así salir a flote. El siguiente poemario de Cerviño, ¿Por qué hay poemas y no más bien nada? (2013) remite en su título a la célebre formulación de Heidegger, heredada a su vez de Leibniz y antes de Parménides, “¿por qué hay ser y no más bien nada?" [warum ist überhaupt Seiendes und nicht vielmehr Nichts?] y es una 
tentativa que debe mucho a la escritura automática ("escribir a tientas / para leer a ciegas"), abocada a la intervención de un lector activo que "poliniza las líneas del texto" (55), que van de lo entrecortado por barras diagonales a la cursiva en que se responde las preguntas invisibles del lector, hasta el torrencial monólogo final. El tanteo de Cerviño, relacionado con la "radical autoconciencia" que, según Vicente Luis Mora (2016: 147) lo caracteriza, es también el de una comunicación más que precaria, pues el poema "de continuo se desdice y, en ese hueco, el lector sobreentiende: los dos vacíos se solapan", con lo que las lecturas no formarían sino "una cadena infinita de malentendidos" (56), una pluralidad de sentidos que el poema suscitaría en el lector. En una versión postmoderna de aquella botella al mar que decía Celan que lanzaba al mar en espera de encontrar algún día su lector adecuado, Cerviño imagina a un poema que acecha al lector: "El poema vampiriza al lector. Animado por una insaciable sed de sentido lo acecha a la vuelta de cada página, contiene la respiración, aguarda expectante -con el aliento mínimo de un no-muerto puede alargar varios siglos la espera- y, llegado el momento, se arrojará, silencioso como una sombra, a la yugular de su víctima para cobrarse su buena ración de significado" (64). En su último poemario, Impersonal (2015), Cerviño se adentra aún más en una polifonía libérrima y el lenguaje desborda completamente cualquier pretensión de identidad unitaria, "sintáctico se encrespa el oleaje / sube la marea léxica y no se hace pie en el poema" (37). Entre la tentación entrópica y la resistencia a la disolución, el poeta concibe la escritura como una natación que intuye la profundidad abisal del lenguaje sobre el que se mantiene. En su último libro, Exogamia (2017), Ángel Cerviño saca a la palestra una polifonía de discursos filosóficos que marida con su libérrima palabra lírica. Cada poema de Exogamia viene encabezado por una cita ajena, que pone en marcha la cabalgada lírica del gallego. Como explica al final del libro, lo que quiso es "enfrentar sobre el espejo de la página dos modalidades bien diferentes de Verdad, dos sistemas quizá antagónicos de credibilidad: el afán especulativo del ensayo científico y el merodeo canoro de la escritura poética". Esa escritura silvestre de Cerviño crece frondosa a partir de las juiciosas sentencias de Freud o Zizek, Sánchez Ferlosio o María Zambrano, desvelando ramas, esquejes o injertos posibles en sistemas teóricos muy dispares. El libro es un canto también a lo inacabado: algunos poemas contienen notas a pie de página que enuncian imágenes "desestimadas en sucesivas correcciones" y que sin embargo se nos muestran tan válidas como las otras. Todo ello en un gozoso aquelarre léxico que sorprende en cada lectura. Y es que, como se dice hacia el final del libro: "Todo poema abre un paréntesis, los mejores se olvidan de cerrarlo".

La recuperación de crédito de las propuestas textuales que subviertan los cánones habituales se percibe también en la evolución de poetas como Mariano Peyrou (nacido en 1971 en Buenos Aires pero afincado desde su infancia en Madrid), quien ha derivado, desde el enfoque claramente figurativo de sus poemarios La sal (2005) y Estudio de lo visible (2007) al netamente rupturista Temperatura voz. (2010), que se presenta como una búsqueda continua de la "temperatura" adecuada, la "candencia" que es cadencia y que se anuncia mediante el "contacto murmúreo" de las palabras esbozadas, que son luego sometidas a una torsión que descoyunta la sintaxis ("te voy a torturar hasta que digas" (41)), todo llevado por "un deseo rebosante de voz" (39). Insatisfecho con los límites que ofrecía su anterior estilo figurativo, el poeta busca desesperadamente "una vía de entrada" hacia lo que él llama "la zona subjuntiva" (28), terreno del deseo y la posibilidad a la que intenta accederse mediante una forma poética que encauce y dé 
forma a una existencia fragmentaria, que "reconstruya la trama la textura / del día fulja" (31), y que se necesita aunque sea a costa de forzar la forma.

Una búsqueda que compartiría en sus premisas y desarrollos con poetas como Ernesto García López (Madrid, 1973), especialmente en el "ejercicio de desborde" que fue su Ritual (2011), donde persigue una "escritura-labranza que todo lo comprime / todo lo trabaja" (73), o Carlos Fernández López (Santiago de Compostela, 1981) en Vitral de vo\% que busca la descomposición de su propia escritura en un espectro métrico con el objetivo de adivinar la inasible identidad, pues, como dice, "me pinto y desarmo la voz / voy tras su dueño" (18).

Desde sus primeros poemarios, Voz (1998), Ética del silencio (2000) y Fiesta de pájaros (2002), la poesía de Ernesto García López (Madrid, 1973) ha venido girando en torno a dos ejes cruzados. De una parte, también en él la indagación sobre la identidad, cuestionada en su aparente homogeneidad y siempre al acecho de la alteridad que nos habita. Al mismo tiempo, el cuestionamiento del lenguaje, la rebelión contra las frases hechas que revelan un pensamiento construido con materiales recibidos de forma acrítica, contra los que el poeta afirmaba su fe en que las palabras redescubiertas, repristinadas por la revelación poética, alumbraran nuevos horizontes en la vida individual y colectiva. Frente al solipsismo inicial de Voz y Ética del silencio, en El desvio del otro (2008) se observaba un deseo de descubrirse en una compañía que no anulara la individualidad sino que la enriqueciera por reacción, tratando así de llegar a "la comprensión del yo pasando por el desvío del otro". El yo poético adoptaba el papel del paseante no tan solitario por los márgenes de París y Londres, con una mirada que se dejaba impregnar de toda la extrañeza posible, para "volver con la voz modificada" presta a derramarse sobre la página. Tras el esbozo de esta poética de la soledad acompañada en El desvío del otro, Ritual, explora los límites de la palabra en cinco etapas claramente definidas, y que, como todo rito, suponen un alejamiento inicial, la superación de una crisis y una final reintegración. De este modo, las cinco secciones de Ritual iban desplegando con creciente extensión y libertad el proyecto poético del autor. La primera, titulada "Monotipos" por su carácter de impresiones únicas, concentradas, apunta ya las obsesiones principales que dominarán el libro: la búsqueda de "la realidad de la realidad" oculta tras lo cotidiano, desvelada por una mirada de la sospecha pero también de la adhesión afectiva a la tierra, "rarificado por todo lo que es raíz", "más ardidos por piedra que por cielo" con un telurismo consciente de nuestra fragilidad y que se refleja en una "fábula de derribo" que se desarrolla en escenarios desolados, playas o descampados, recorridos por animales aislados, imagen de nuestra "soledumbre". Al mismo tiempo se evidencia la necesidad de luchar con el lenguaje para desnudarlo de adherencias espurias y "desintegrar su mecánica" para así descubrir por qué pensamos como pensamos, cómo se forma nuestra conciencia del mundo, como paso previo para ampliar nuestra visión y nuestros horizontes.

Estas impresiones dispersas van condensándose y en la segunda parte, "Alquimia del dolor", se desgranan en las veintiuna secuencias que describen el complejo proceso de un sujeto aislado, encerrado en su "hervidero de soledad", que lucha por distanciarse de sí mismo y concebirse en su extrañeza, atisbando al tiempo una "sobrevida temblando por encima de lo real”, esa realidad oculta en la que el poeta sigue creyendo como en una última fe, que persigue mediante caminos que eviten los espectáculos y simulacros con los que se nos intenta engatusar, apostando por "el desplazamiento, / la asonada, / el desborde", medios que nos recuerdan la 
teoría de la deriva de Guy Debord y a su puesta en práctica poética en su anterior libro, donde "la constancia errática del flâneur" iba recogiendo iluminaciones inesperadas. Sin embargo, frente al ludismo surrealista del azar objetivo, la palabra de García López exprime y expresa el sufrimiento que tan bien conoce en sí mismo y en los otros (téngase en cuenta que Ernesto García trabaja como cooperante en distintos proyectos humanitarios): "Otra cosa el dolor (¿te acuerdas?) / del que sabemos tan poco / y es tangible / y muerde”. Ernesto García se empeña en la excavación de la identidad y su cuestionamiento permanente, en una indagación tan intensa en sus hontanares, que corre el riesgo de agotarlos, escurriéndose los gránulos de nuestro ser entre los dedos que escriben, dejándonos sin otra respuesta que la misma búsqueda: "Como una cavadura / sin hallazgo / que a sí misma se contiene". Como antepasados reconocidos de esta búsqueda tenaz, en la sección "Linajes" de la tercera parte, Ernesto García destaca a Ítalo Calvino, de quien aprendió la inquietud por la carencia que siempre nos socava, tratada de forma irónica por ejemplo en El vizconde demediado, al que se alude implícitamente; pero también se admite el parentesco con una larga serie de luchadores contra el dogmatismo y fundadores de la duda, desde John Wiclef a Miguel Servet, aún ampliable si recorremos la bitácora que, también con el título de Ritual, mantuvo el autor durante algunos años y ha retomado recientemente.

En esta sección central del poemario, titulada "El grito es un movimiento inacabado", el cauce de la búsqueda interior a través de distintos registros poemáticos se ensancha en amplios textos en prosa, para seguidamente desbordarse en la cuarta sección, "Corte arbitrario", largo poema que abarca ocho páginas y donde los significantes se tratan con un atrevimiento y desparpajo ya libres de toda contención, llevándose a la práctica las consignas enunciadas anteriormente. Situado en "lugares indiferentes" o "abúlicos", en los "no-lugares" de los que hablara Marc Augé, el poeta deja esparcir la mirada como una red para desordenar la realidad en torno y alcanzar esa otra realidad oculta. En ello coincide con una imaginería de la visión como órgano prensil y artífice, que transforma y no sólo refleja, y que encontramos en otros poetas cercanos, esos poetas de la mirada que hemos mencionado, que sin embargo tienden más al verso contenido y no al derrame apabullante de las últimas secuencias del libro de Ernesto García. La dispersión de los significantes, incluso su segmentación, el juego con la disposición tipográfica o la ruptura de los vínculos sintácticos, todo conspira a favor de lo arbitrario, del "devenir" y la "deriva", salpicado de nuevo este escenario por las imágenes inquietantes de esa fábula de derribo de la que se hablaba al principio, donde coexisten antílopes muertos con restos de plástico o vinilo. Todo ello como protesta tanto contra la macroestructura económica, frente a la que se cantan las "huelgas hermosas como madrugadas", como al lenguaje anquilosado que nos entumece, pues, como expresa provocativamente: "llevamos tiempo dejándonos hablar por la boca".

Tras el desborde casi dionisíaco de "Corte arbitrario", el poema "Ritual" que cierra el libro sirve para fijar la maduración lograda a través del proceso recorrido, a la vez que se enuncia el deber de memoria que justifique este camino, de "no olvidar" lo vivido en esos momentos en los que "las palabras ardieron", a pesar de que luego la vida entierre ese milagro y esa "resaca gloriosa". Ese desborde ha logrado sacar al poeta y con él, al lector, de su "soledumbre" hacia las calles, en cuyo tráfago, en contacto con los otros, logra reunir su "manojo de fracturas que hoy me recomponen" y convertirse en un latir ya no tan solitario. Según se enuncia en este último 
poema, sin duda el más programático y definitorio de su poética: "No en soledad. Somos muchos". Esa tensión hacia lo colectivo se abre aún más en su último poemario, Todo está en todo (2016), marcado por la experiencia del autor en la participación de los movimientos del 15-M.

La evolución hacia poéticas rupturistas desde una línea relativamente tradicional es aún más llamativa en el caso de Alejandro Céspedes (Gijón, 1958), cuya trayectoria, desde La noche y sus consejos (1986) hasta Flores en la cuneta (2009), aunque sorprendente en su temática (los accidentes de tráfico en el último caso) podía enmarcarse en un realismo previsible, no hacían predecir la ruptura que supuso Topología de una página en blanco (2012), libro concebido como reflexión sobre el proceso creativo, como "poesía que se piensa en el lenguaje mientras está produciéndolo" y que quiere "atentar contra todo lo sencillo", dinamitando las convenciones gráficas mediante caligramas y artificios en el límite con la poesía visual, con versos en vertical, diagonal y espirales en forma de pozo. Confiado en la fragmentación y dispersión de los significantes para lograr nuevos significados, se afirma que "en lo que no se ha dicho están los manantiales / del lenguaje / y en lo que se ha roto / está nuestro mejor acto de escritura / convierte en posesión lo que destruyes" (66). El exilio y la diáspora se enarbolan como lugares de promisión ("diáspora y paradiso tienen las mismas letras" (80)) donde sea "posible habitar en las palabras" (92), lo cual no debe hacernos inferir un solipsismo que prescindiera del lector. Muy al contrario, se recuerda que "hay cosas / que ocurren más allá del envés de estas mismas palabras" y que sólo pueden alcanzarse con "la complicidad / de tus dos ojos" (92), algo que se demuestra del modo más llamativo en el espejo de la página 53, donde el lector puede leer reflejado el poema de la página anterior a la vez que se encuentra con su propio rostro.

En este contexto era lógica la revaloración de poéticas como la de José-Miguel Ullán, de la que es heredero directo Enrique Cabezón (Logroño, 1976) quien se desmarca claramente de sus poemarios anteriores, enmarcables en una corriente de realismo sucio, en su libro Desdecir (2013) que procede a la tachadura de un poema que persiste y resiste, a pie de página, a la vez que los borrones hacen surgir otro texto distinto, de modo que ambas posibilidades conviven, mostrando una doble lectura que paradójicamente al suprimir palabras reanima un lenguaje que se considera momificado: "nos dijeron que vaciásemos de contenido la palabra "escritura" / como el molde de escayola / de la cara de un muerto / un vaciado de formas quietas // nos dijeron que no hurgásemos en ese extraño lugar / donde se muerden el cuello veracidad y verosimilitud / ese espacio fértil entre artificio y mentira" (28). En su epílogo "Algunas notas para desdecirme", Cabezón da cuenta del largo proceso de elaboración de un libro que, iniciado como una purga del corazón, vio como tiempo después la ficción entraba de lleno en ellos: “¿Quién era yo? ¿Quién escribió esos poemas? -reclamaron escenario, personajes, acción... y apartaron a un segundo plano al "yo" introspectivo y desencantado que había protagonizado mi trabajo hasta entonces" (130). Esa conciencia de la espectacularidad que sustituye a la especularidad del poema se compagina con la de su perpetua imperfección o, lo que es lo mismo, su incesante modificación: "Me desdigo para decir de nuevo en un bucle recurrente al que no quiero renunciar".

Quizás esté llegando el momento de valorar justamente, más allá de tópicos y prejuicios la obra de José-Miguel Ullán y haya llegado aquel despertar que él echaba en falta: "Ten paciencia: / no debe de haber nadie / todavía despierto allí del todo” $(2008,1025)$. Algunos indicios, como la 
futura edición de sus artículos y reseñas, o la tesis doctoral que, desde la estética y la filosofía, le dedica Rosa Benéitez (de próxima publicación) parecen apuntar en este sentido.

Pero quizás nadie haya insistido más en esta disgregación y proliferación de la propia voz en una polifonía de voces que Julio César Galán (Cáceres, 1978), quien combina la obra firmada con su nombre con la de distintos heterónimos de ambos sexos. Desde su primer poemario, El ocaso de la aurora (2004) asistimos al nacimiento de una voz celebratoria, muy juanramoniana a veces y pasada por el tamiz del panteísmo postromántico y a veces surrealista de Vicente Aleixandre. Una vertiente en la que muestra claras afinidades con otros poetas, como José Luis Rey (Puente Genil, 1973) y Juan Andrés García Román (Granada, 1979), formando otra tríada de poetas caracterizados por su visión celebratoria e hímnica de la poesía. Galán muestra la fe en la poesía como mundo autónomo, buscando "las palabras que nunca vivieron / en boca humana" (23). En Tres veces luz (2007) siguió buscando fabricar "la casa maravillosa" del lenguaje mediante sorprendentes imágenes visionarias, consecuente con una concepción según la cual "cada cosa es un viaje" o "una correspondencia" que ha de establecer el poeta, pero no por una armonía preestablecida que el vate fuera el único en discernir, sino por la firme voluntad de hacer más bello y soportable el mundo, una pasión de domeñar el lenguaje que encuentra su recompensa en sí misma, como el alpinista encuentra satisfacción en vencer a la montaña. En su último libro firmado con su nombre, Inclinación al envés (2013) a través de la simbología antigua del pájaro como poeta convoca múltiples tradiciones (romanticismo, barroco, surrealismo) que disuelven y borran la identidad, cuestionando sus propias palabras desde las notas que llevan algunos poemas, cuya cualidad inestable se remarca además con la inclusión, también en nota, de versiones preliminares de algunos fragmentos. Como ha señalado Eduardo Moga, en este poemario "se expone, sin temor a las cicatrices, el proceso de escritura; más aún, el proceso de escritura, titubeante, desgreñado, se convierte en poema. Julio César Galán siente la necesidad de decir, sin ocultar el camino, casi siempre tortuoso, que ese decir recorre" (2015, 141). En su "viaje hacia sî" Julio César Galán, tras "introducirse en el hueco / caótico de uno mismo”, como decía en Márgenes $(2010,20)$ ha terminado por descubrir en la polifonía y la diseminación en otras voces la mejor manera de reconciliar las contradicciones de su personalidad, creando heterónimos bajo cuyas firmas ha publicado tres poemarios, en un gesto inusitado y provocador en un panorama tan personalizado como el ámbito de la poesía. Así, Gajo de sol (2008) del místico panteísta Luis Yarza, ¿Baile de cerezas o polen germinando? (2010) del vanguardista Pablo Gaudet o Introducción a la locura de las mariposas (2015), de Jimena Alba, pueden verse como la afirmación vitalista de las distintas virtualidades que coexisten en nosotros.

\section{¿ANTE UNA NUEVA VANGUARDIA?}

La disparidad de las propuestas poéticas que hemos expuesto brevemente no permite, seguramente, hablar de un movimiento único, discernible, que pudiera englobar a autores tan diversos. Sin embargo, y a pesar de la disparidad formal, desde el versículo largo de Esther Ramón o José Antonio Llera a la poesía fragmentada de Ángel Cerviño, Yaiza Martínez o Enrique Cabezón, pasando por el verso libre de Julio César Galán o el poema disperso de Alejandro Céspedes, vemos un cuestionamiento del lenguaje y un intento por aferrar, en su materialidad y su devenir, una nueva forma de introspección y comunicación posterior con un 
lector abierto a nuevos usos del lenguaje. Después de más de dos décadas de hegemonía de la poesía figurativa conocida como poesía de la experiencia, podemos coincidir con Eduardo Moga cuando afirma que han surgido poéticas "relacionadas con una concepción experimental, indagatoria, transgresora de la palabra" $(2013,171)$. No sería adecuado hablar simplemente de "metapoesía", sino que se trata más bien de la conciencia de que sólo mediante la distancia que posibilita la escritura se puede expresar lo más íntimo o, como dice Alejandro Céspedes, "este folio construye la distancia / no hay dentro o fuera al / traspasar la línea" (2013, 89). Frente al clasicismo del poema "bien hecho", armónico, estas poéticas tienen en común la idea de que más que el fin, importa el proceso, la poesía como reflejo de un acto de construcción progresivo, y idea que el poema es aprendizaje por descubrimiento o por accidente. Más que en antologías, esos antiguos retratos de familia, estos poetas conciben su creación como un constante flujo y nos abren los ojos a la necesidad de dar cuenta de la poesía como transcurso y transformación incesante. 


\section{BIBLIOGRAFÍA}

ALBA, Jimena (2015). Introducción a la locura de las mariposas. Madrid: Tigres de Papel, 2015.

BenÉitez, Rosa (2009). “Agua. Yaiza Martínez”, Afterpost. Espacio de crítica literaria y cultural.

Bourdieu, Pierre (1992). Les règles de l'art. Genèse et structure du champ littéraire. París: Seuil.

CABEZÓn, Enrique (2012). Desdecir. Madrid: Amargord.

CANTELI, Marcos (2003). enjambre. Madrid: Bartleby.

CANTELI, Marcos (2005). su sombrío. Barcelona: DVD Ediciones.

CANTELI, Marcos (2008). Catálogo de incesantes. Madrid: Bartleby.

CANTELI, Marcos (2014). Del parpadeo. 7 poéticas. Madrid: Libros de la Resistencia.

CÉSPEDES, Alejandro (1986). La noche y sus consejos. Granada: Genil.

CÉSPEDES, Alejandro (2009). Flores en la cuenta. Madrid: Hiperión.

CÉSPEDES, Alejandro (2012). Topología de una página en blanco. Madrid: Amargord.

CERVIÑO, Ángel (2007). Kamasutra para Hansel y Gretel. Madrid: Ediciones Eventuales.

CERviÑo, Ángel (2009). El ave fénix solo caga canela, Barcelona, DVD Ediciones.

CERVIÑO, Ángel (2013). ¿Por qué hay poemas y no más bien nada?, prólogo de Luis Luna. Madrid: Amargord.

CERviÑo, Ángel (2015). Impersonal, prólogo de Eduardo Moga. Madrid: Amargord.

CERviÑo, Ángel (2017). Exogamia. Cáceres: Ediciones Liliputienses.

CURIESES, Óscar (2007). Sonetos del útero. Madrid: Bartleby.

CuRIESES, Óscar (2010). Dentro. Madrid: Bartleby.

CURIESES, Óscar (2013a). hay una jaula en cada pájaro. Madrid: Ya lo dijo Casimiro Parker.

CuRIESES, Óscar (2013b). Hombre en azul. Zaragoza: Jekyll \& Jill.

DíAz, Rafael-José (2003). Los párpados cautivos. Las Palmas: Cabildo Insular de Gran Canaria.

DíAZ, Rafael-José (2014). El interior del párpado. Madrid: ATTK Editores.

GaLÁn, Julio César (2004). El ocaso de la aurora. Madrid: Sial.

GALÁn, Julio César (2007). Tres veces luz: Barcelona: La Garúa.

GaLÁn, Julio César (2010). Márgenes. Valencia: Pre-Textos.

GALÁN, Julio César (2014). Inclinación al envés, Valencia, Pre-Textos.

García López, Ernesto (1998). Voz: Madrid: Ópera Prima.

GARCíA LÓPEZ, Ernesto (2000). Ética del silencio. Madrid: Vitruvio.

GARCíA LÓPEZ, Ernesto (2002). Fiesta de pájaros. Madrid: Devenir. 
GARCía LóPEZ, Ernesto (2011). Ritual, prólogo de Mercedes Roffé. Madrid: Amargord.

GARCÍA LÓPEZ, Ernesto (2016). Todo está en todo. Madrid: Amargord.

GAUDET, Pablo (2010). ¿Baile de cerezas o polen germinando?, Santa Cruz de Tenerife, Ediciones Idea.

Gómez Toré, José Luis (2010). “Ángel Cerviño, El ave fénix solo caga canela”, Koult.

Gorría, Ana (2005). Araña. Almería: El Gaviero.

Lacoue-Labarthe, Philippe (2015): La poésie comme expérience. París: Christian Bourgeois Éditeur (1 ${ }^{\mathrm{a}}$ ed 1986).

LLERA, José Antonio (1999): Preludio a la inmersión. Mérida: Editora Regional de Extremadura.

LLERA, José Antonio (2007): Monólogo de Homero. Mérida: Editora Regional de Extremadura.

LLERA, José Antonio (2009): El sindrome de Diógenes. Gerona: Luces de Gálibo.

LLERA, José Antonio (2013a): Rostros de la locura. Goya. Cervantes. Wiseman. Madrid: Abada.

LLERA, José Antonio (2013b): Transporte de animales vivos. Badajoz: Aristas Martínez.

Lloze, Évelyne (2013). Poésie et question. De la poésie comme pensée critique. Bruselas: La Lettre Volée.

LÓPeZ CARBAllo, Pablo (2010). Sobre unas ruinas encontradas. Barcelona: La Garúa.

López Carballo, Pablo (2011). “Conversación con Pablo López Carballo”, Culturamas.

López Carballo, Pablo (2012). Quien manda uno. Madrid: Amargord.

LÓPez Carballo, Pablo. “Pájaro incómodo". Nayagua. Revista de poesía 20 (2014): 185-187.

López Carballo, Pablo (2017). La dictadura de la perspectiva. Gijón: Trea.

MARTíneZ, Yaiza (2002). Rumia Lilith. Gijón: Ateneo Obrero de Gijón.

MARTínEZ, Yaiza (2007). El hogar de los animales Ada. Madrid: Devenir.

Martínez, Yaiza (2007). Agua. Santa Cruz de Tenerife: Idea.

MARTíneZ, Yaiza (2010). Siete. Los perros del cielo. Madrid: Leteo.

MARTÍNEZ, Yaiza (2012). Caoscopia. Madrid: Amargord.

Méndez Rubio, Antonio (2012). La desaparición del exterior. Cultura, crisis y fascismo de baja intensidad. Zaragoza: Eclipsados.

MÉNDEZ Rubio, Antonio (2015). "Pájaro sin alivio", epílogo a: Esther Ramón, Desfrío. Madrid: Varasek: 79-84.

MogA, Eduardo. "Algunos nombres impropios", Cuadernos Hispanoamericanos, 757-758 (julioagosto) (2013):171-187.

MogA, Eduardo (2015a). "Los habitantes del río", Quimera. Revista de Literatura, 377 (abril) (2015): 66.

MogA, Eduardo (2015b). La disección de la rosa. Mérida, Editora Regional de Extremadura. 
MORA, Vicente Luis (2006). Singularidades. Ética y poética de la literatura española actual. Madrid: Bartleby.

MORA, Vicente Luis (2016). El sujeto boscoso. Tipologías subjetivas de la poesía española contemporánea entre el espejo y la notredad (1978-2015). Madrid/Frankfurt: Iberoamericana/Vervuert.

Morales Barba, Rafael (ed.) (2017). Poéticas del malestar. Antología de poetas contemporáneos. Prólogo de Antonio Gamoneda. Bilbao: Ediciones El Gallo de Oro.

Peyrou, Mariano (2005). La sal. Valencia: Pre-Textos.

Peyrou, Mariano (2007). Estudio de lo visible. Valencia: Pre-Textos.

Peyrou, Mariano (2010). Temperatura voz, Valencia, Pre-Textos.

Pliego, Benito del (2009). Merma. Santa Cruz de Tenerife: Baile del Sol.

RAMÓN, Esther (2002). Tundra. prólogo de Juan Carlos Suñén, Tarragona, Igitur.

RAMÓN, Esther (2008). Reses. Gijón: Trea.

RAMÓN, Esther (2009). Grisú. Gijón, Trea.

RAMÓn, Esther (2011). Sales, fotografías de Mark Bentley. Madrid: Amargord.

RAMÓN, Esther (2013). Caza con burones. Barcelona: Icaria.

RAMÓn, Esther (2015a). Desfrío, epílogo de Antonio Méndez Rubio. Madrid: Varasek.

RAMÓN, Esther (2015b). Moradas. Madrid: Calambur.

RAMÓn, Esther (2017). en flecha. Madrid: La Palma.

TORRe, Óscar de la (2016). "Prólogo. Non finito (Un deseo llamado punto de fuga)", en: Óscar de la Torre (ed.), Limados. La ruptura textual en la poesía española. Antología. Madrid: Amargord: 11-75.

UlLán, José-Miguel (2008): Ondulaciones. Poesía reunida (1968-2007), prólogo de Miguel Casado. Barcelona: Galaxia Gutenberg.

VEGA, Joan de la (2006). Ladino. Gijón: Trea.

VEGA, Joan de la (2011). La montaña efímera, prólogo de Mario Martín Gijón. Barcelona: Paralelo Sur.

VEGA, Joan de la (2012). 365 haikus y un jïsey, Barcelona: Rúbrica.

VegA, Joan de la (2013). Y tú, Pirene. Valencia: Denes.

YARZA, Luis (2008). Gajo de sol. Cáceres: Institución Cultural El Brocense. 